\title{
ESTIMATION OF THERMODYNAMIC ISOTHERMS FOR MN ADSORPTION IN SOME CALCAREOUS SOILS AT SULAIMANI GOVERNORATE.
}
Sh. M. Sheikh-Abdullah
K. H. Karim
S. M. Mohammed Ali
D. H. T. Faraj
Assist. Prof.
Lecturer
Researcher
Researcher
shuela.abdulla@univsul.edu.iq kamal.hamakarim@univsul.edu.iq
sayranmajed@yahoo.com dla_jaff68@yahoo.com

Dept. of Soil and Water Sci., Coll. of Engineering Agric. Sci., University of Sulaimani,

Directorate of Agric. Research in Sulaimani, Kurdistan Region, Iraq.

\section{ABSTRACT}

This study was conducted to determine the description of Mn adsorption phenomena through adsorption isotherms in some calcareous soils at Sulaimani governorate. Soil samples were taken at 0$30 \mathrm{~cm}$ depth from five different agricultural locations. Duplicate $1 \mathrm{gm}$ of soil samples were equilibrated at 298 and $318{ }^{\circ} \mathrm{K}$ with $50 \mathrm{ml}$ of $0.01 \mathrm{M} \mathrm{CaCl} \mathrm{Cl}_{2}$ containing $(0,2.5,5,10,20$, and 40$) \mathrm{mg} \mathrm{Mn}$ $\mathrm{L}^{-1}$ as $\left(\mathrm{MnSO}_{4} . \mathrm{H}_{2} \mathrm{O}\right)$. The concentration of Mn determined in solution by using ICP-OES. The amount of $\mathrm{Mn}$ adsorbed by each soil samples was calculated. The thermodynamic parameters $\Delta \mathbf{H}^{\circ}, \Delta \mathrm{G}^{\circ}, \Delta \mathrm{S}^{\circ}$ were determined using adsorption data and concentration of $\mathrm{Mn}$ in equilibrium solution at two different temperatures. The results indicated that the Freundlich equation is the best model to describe Mn adsorption in studied soils due to the result the higher $\left(\mathbf{R}^{2}\right)$, with lower (RMSE) and (AIC). The results of $\left(\Delta \mathrm{H}^{\circ}\right)$ indicated that the Mn adsorption processes in the Sharazor, Qaradagh and Mawat soils were exothermic reactions. While, the Mn adsorption processes in both Bazian and Surdash locations were endothermic reactions. The $\left(\Delta S^{\circ}\right)$ values of these soils were as follows: Surdash $>$ Bazian $>$ Sharazor $>$ Qaradagh $>$ Mawat. The results of $\left(\Delta G^{\circ}\right)$ indicated that the reaction in all studied soil locations at temperature $298{ }^{\circ} \mathrm{K}$ is spontaneous, also the reaction stay spontaneous with increase temperature to $318^{\circ} \mathrm{K}$ only in both Bazian and Surdash locations.

Key words: Manganese, adsorption models, Thermodynamic parameters, Batch equilibrium

عبد الله وآخرون

1055-1046:(4)50:2019- مجلة العلوم الزراعية العراقية

تقدير طاقة الحراري لأمتزاز المنغتيز في بعض التربة الكلسية في محافظة السليمانية.

$$
\begin{aligned}
& \text { دلسوز حمه طالب فرج } \\
& \text { سيران مجيا محمد علي } \\
& \text { كمال حمه كريم } \\
& \text { باحث } \\
& \text { مديرية بحوث الزراعية في السليمانية - كردستان العراق }
\end{aligned}
$$

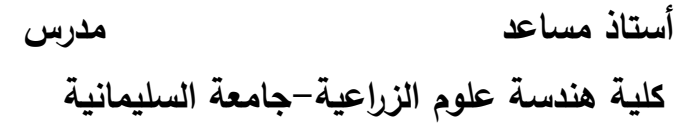

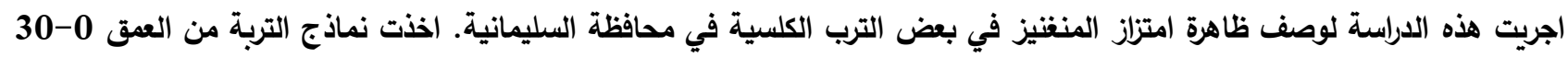

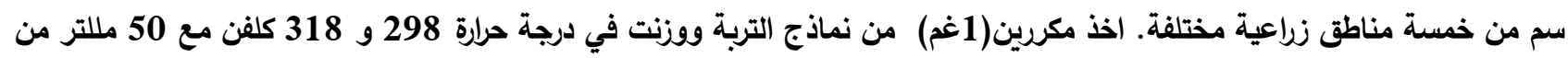

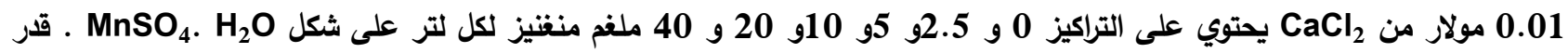

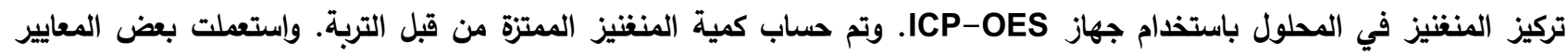

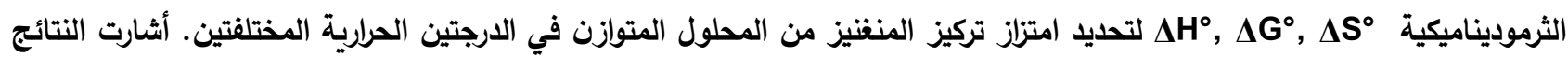

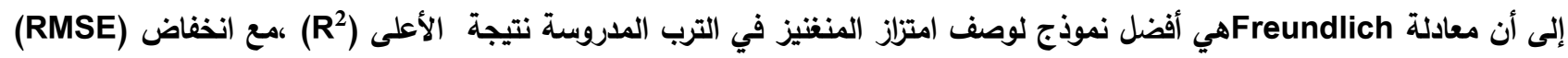

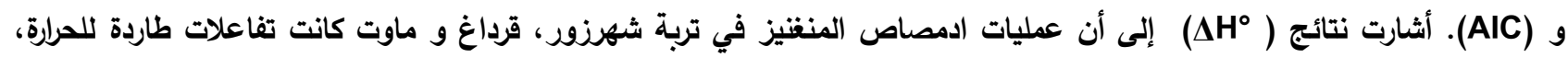

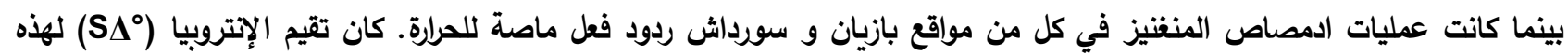

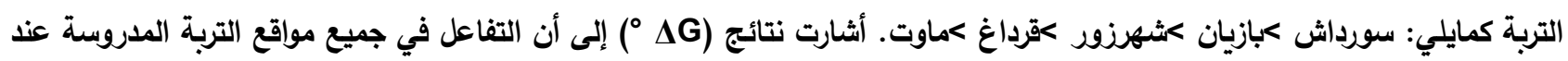

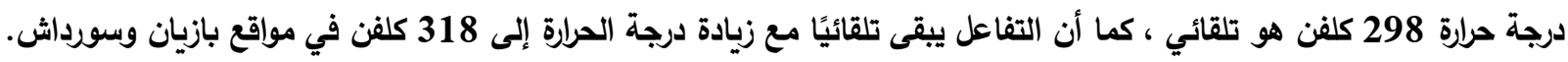
كلمات مفتاحية: نماذج تربة، مناطق زراعية، الحرارة، الانتروبيا. 


\section{INTRODUCTION}

Manganese $(\mathrm{Mn})$ is an important element in the earth crust, and is the eleventh element, its average content of total $\mathrm{Mn}$ in soils is estimated of $900 \mathrm{mg} \mathrm{kg}^{-1}$ (5). In agricultural area, adsorption of ionic form of elements from the soil solution by soil particle is an interest process for determine soil properties such as soil fertility (8). Adsorption of elements is processes of retention elements from the solution by the surface during a time and then reversible process will occur (28). There are many factors that affect $\mathrm{Mn}$ adsorption in soils which is: soil organic matter, $\mathrm{pH}$ of soil solution, and cation exchange capacity (20). Heavy metal adsorption and their distribution are mainly depending on many parameters which is soil type, metal speciation, metal concentration, and soil $\mathrm{pH}$ (10, 25 and 22). In general, soils with $\mathrm{pH}$ alkaline often have the higher ability to adsorptions metal, since these soils have lower solubility $(6,29$, and 30). The bioavailability of $\mathrm{Mn}$ in soils significantly decreases with high $\mathrm{pH}$ value (16). Manganese is an essential element for the plant which needed in a small amount, the availability of this element chiefly depending on soil reaction. As we know Sulaimani Governorate soils is calcareous soil and have $\mathrm{pH}$ neutral to alkaline, so these cause to decrease the availability of this element in our agriculture soil, also the forms of the element changed in the soil, so we need to know the amount of Mn adsorbed in this area. Few studies have been carried out to identify the adsorption of $\mathrm{Mn}$ in the Sulaimani soils. For this reason this study was selected to evaluate: (i) the description of $\mathrm{Mn}$ adsorption phenomena through some adsorption isotherms and the individual adsorption behavior of $\mathrm{Mn}$ in calcareous soils. (ii)Using some isotherm models to assess which model will be fit with the Manganese adsorption. (iii)To determine the relation between soil properties and Mn adsorption in studied area.

\section{MATERIALS and METHODS}

\section{Description of field sampling locations:}

This study conducted on the five Agricultural soil samples around Sulaimani region, the sampling sites are located in Sharazor (N $35^{\circ} 15^{\prime} 27^{\prime \prime}$; E $45^{\circ} 42^{\prime} 21^{\prime \prime}$ ), Qaradagh (N 35 $20^{\prime} 00^{\prime \prime}$; E $45^{\circ} 25^{\prime} 12^{\prime \prime}$ ), Bazian (N 35 37' 01"; E $45^{\circ} 05^{\prime} 38^{\prime \prime}$ ), Mawat (N 35 52' 34"; E $45^{\circ} 24^{\prime} 35^{\prime \prime}$ ), and Surdash (N 35 46' 09"; E $\left.45^{\circ} 07^{\prime} 37^{\prime \prime}\right)$.

\section{Sample collections}

Soil samples were collected from 5 locations around Sulaimani, soil samples were taken from depth $0-30 \mathrm{~cm}$ to the Laboratory. Samples were air dried for a few days then sieved through sieve $2 \mathrm{~mm}$ and then storage in plastic bags to use for some chemical and physical analysis.

\section{Laboratory analysis: Physico-chemical analysis}

Several physical and chemical analyses were done for whole soil samples. The particle size distribution was determined using the pipette method described by (33). Soil reaction $(\mathrm{pH})$ of the saturation extract was measured with $\mathrm{pH}$-meter, and EC was determined according to (33). Total $\mathrm{CaCO}_{3}$ equivalent was determined according to the method described by (19). Soil organic matter was determined using the Walkley-Black wet digestion method (32). Available Mn was extracted by using $\left(0.005 \mathrm{M}\right.$ DTPA + $0.01 \mathrm{M} \mathrm{CaCl}_{2}+0.1 \mathrm{M}$ TEA $)$ method. Extractable $\mathrm{Mn}$ was measured by using ICP as described in (24).

\section{Batch equilibrium for Mn adsorption}

Adsorption process was studied by equilibrating a duplicate $1 \mathrm{gm}$ of soil samples was placed in plastic bottles and equilibrated with $50 \mathrm{ml}$ of $0.01 \mathrm{M} \mathrm{CaCl}_{2}$ solution to keep the ionic strength almost constant, containing a series of Mn concentrations 0, 2.5, 5, 10, 20, and $40 \mu \mathrm{g} \mathrm{Mn} \cdot \mathrm{gm}^{-1}$ as $\left(\mathrm{MnSO}_{4} \cdot \mathrm{H}_{2} \mathrm{O}\right)$, two drops of toluene were added to each suspension to inhibit microbial activity. The suspension was shaken for $30 \mathrm{~min}$. and then kept it at two difference temperatures $298^{\circ} \mathrm{K}$ and $318^{\circ} \mathrm{K}$. The soil suspensions were immediately filtered through whatman paper No.42, then the concentration of $\mathrm{Mn}$ determined in solution by using ICP-OES. The amount of $\mathrm{Mn}$ adsorbed by each soil samples was calculated from the difference between the initial and final concentration in the extract solution.

\section{Adsorption isotherm}

Langmuir, Freundlich, Temkin and DubininRadushkevich isotherm were used to describe $\mathrm{Mn}$ adsorption in studied area. 


\section{Langmuir isotherm}

The Langmuir adsorption isotherm Langmuir, I. (23) was used to interpret adsorption phenomena. The linear form of Langmuir isotherm given in equation 1 :

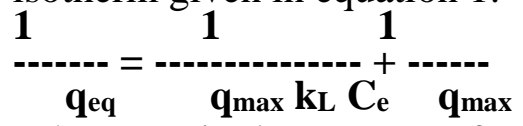

Where $\mathrm{q}_{\mathrm{eq}}$ is the amount of $\mathrm{Mn}$ adsorbed (mg $\left.\mathrm{g}^{-1}\right), \quad \mathrm{q}_{\max }$ is the maximum capacity of adsorption $\left(\mathrm{mg} \mathrm{g}^{-1}\right), \mathrm{kL}$ is an equilibrium constant $\left(\mathrm{L} \mathrm{mg}^{-1}\right)$ related to adsorption energy which reflects the affinity between the adsorbent and adsorbate, and $\mathrm{C}_{\mathrm{e}}$ is the concentration of $\mathrm{Mn}$ at equilibrium in $\left(\mathrm{mg} \mathrm{L}^{-}\right.$ ${ }^{1}$ ). The Langmuir adsorption isotherms were drawn by plotting the ratio of one over the amount of $\mathrm{Mn}$ adsorbed against one over equilibrium $\mathrm{Mn}$ concentration.

Freundlich isotherm model: The linear form of Freundlich adsorption isotherm Freundlich, H. (17) was used as shown in equation 2.

$\log \mathrm{q}_{\mathrm{eq}}=\log \mathrm{K}_{\mathrm{F}}+1 / \mathrm{n} \log \mathrm{C}_{\mathrm{e}}$

Where, $\mathrm{q}_{\mathrm{eq}}$ is amount of $\mathrm{Mn}$ adsorbed $\left(\mathrm{mg} \mathrm{g}^{-1}\right)$, $\mathrm{K}_{\mathrm{F}}$ is the Freundlich constant related to sorption capacity in $\left(\mathrm{mg} \mathrm{g}^{-1}\right), \mathrm{n}$ is related to the intensity of adsorption for the adsorbent, and $\mathrm{C}_{\mathrm{e}}$ equilibrium constant of $\mathrm{Mn}\left(\mathrm{mg} \mathrm{L}^{-1}\right)$. The Freundlich constants were calculated from linear plot between $\log \mathrm{q}_{\mathrm{e}}$ against $\log \mathrm{C}_{\mathrm{e}}$.

Temkin isotherm model: The Temkin isotherm was used to calculate the interactions between adsorbents and adsorbed elements in ionic form Das, B. et al.(12). The linear form of the Temkin isotherm shown in equation 3 .

$q e=B \ln A+B \ln C_{e}$

Where: qe is the amount of $\mathrm{Mn}$ adsorbed at equilibrium $\left(\mathrm{mg} \mathrm{g}^{-1}\right), \mathrm{A} \& \mathrm{~B}$ are constant, $\mathrm{B}$ is the heat of adsorption and $\mathrm{A}$ is the binding of equilibrium constant $\left(\mathrm{L} \mathrm{min}{ }^{-1}\right)$ conforming to the maximum binding energy, and $\mathrm{Ce}$ is concentration of $\mathrm{Mn}$ at equilibrium $\left(\mathrm{mg} \mathrm{L}^{-1}\right)$

Temkin isotherms were drawn by plotting the amount of $\mathrm{Mn}$ adsorbed $\left(\mathrm{q}_{\mathrm{e}}\right)$ against nature $\log$ equilibrium solution of Mn concentration (ln $\mathrm{C}_{\mathrm{e}}$ ).

Dubinin-Radushkevich isotherm; The Dubinin-Radushkevich (D-R) isotherm model Dubinin, et al (14) and Dubinin (15) was used to interpret the adsorption technique in heterogeneous surface (11). The linear form can be written as following equation 4 .

$\ln q_{e}=\ln q_{D}-2 B_{D} R T \ln \left(1+1 / C_{e}\right)$

Where, qe is the amount of Mn adsorbed (mg $\left.\mathrm{g}^{-1}\right), \mathrm{q}_{\mathrm{D}}$ is the maximum adsorption capacity $\left(\mathrm{mg} \mathrm{g}^{-1}\right), \quad \mathrm{B}_{\mathrm{D}}$ is Dubinin-Radushkevich isotherm constant, $\mathrm{R}$ is the gas constant $(8.314$ $\mathrm{kJ}$ mol), $\mathrm{T}$ is temperature, $\mathrm{Ce}$ is $\mathrm{Mn}$ concentration at equilibrium $\left(\mathrm{mg} \mathrm{L}^{-1}\right)$

Standard free energy $\left(\Delta \mathrm{G}^{\circ}\right)=-\mathrm{RT} \ln \mathrm{K}^{\circ}$

The enthalpy $\Delta \mathrm{H}^{\circ}$ calculated from integrated form of the Vant Hoff equation:

$\ln \mathrm{K} 2 / \mathrm{K} 1=\Delta \mathrm{H}^{\circ} / \mathrm{R}[1 / \mathrm{T} 1-1 / \mathrm{T} 2]$

The standard entropy $\left(\Delta \mathrm{S}^{\circ}\right)=\left(\Delta \mathrm{H}^{\circ}-\Delta \mathrm{G}^{\circ}\right) / \mathrm{T}$

\section{RESULTS AND DISCUSSION}

Soil properties: The soil properties of five agriculture soils shown in Table 1, the soils were difference in texture classes ranging from (loam to Silty clay) which it means that the texture of these soils ranged from fine to moderately textured soils, $(\mathrm{pH})$ value of soil samples ranged between (7.48 -7.9), and the soil were slightly to moderately alkaline. Electrical conductivity (EC) of the soil samples ranged between $\left(0.4-0.9 \mathrm{dS} \mathrm{m}^{-1}\right)$, this shows that the soil studied are non saline and this might be due to relatively higher precipitation and topography of these locations, which caused leaching of salts by natural drainage. Total Calcium carbonate $\left(\mathrm{T}^{\left.-\mathrm{CaCO}_{3}\right)}\right.$ ranged between $\left(25-430 \mathrm{mg} . \mathrm{kg}^{-}\right.$ $\left.{ }^{1}\right)$. This indicates that all soils are considered to be calcareous soils. Organic matter contents varied between the studied soils and ranged from $\left(9-25 \mathrm{~g} \mathrm{~kg}^{-1}\right)$. The values of DTPAextractable $\mathrm{Mn}$ ranged between 1.198-3.833 $\mathrm{mg} \mathrm{kg}^{-1}$ in soil samples.

Table 1. Chemical and physical properties in studied soil samples

\begin{tabular}{|c|c|c|c|c|c|c|c|c|c|c|}
\hline Locations & pH & $\begin{array}{c}\text { Ec } \\
\left(\mathbf{d s} \mathbf{~ m}^{-1}\right)\end{array}$ & $\begin{array}{c}\text { T.CaCO} 3 \\
\left(\mathrm{~g} \mathrm{~kg}^{-1}\right) \\
\end{array}$ & $\begin{array}{c}\text { O.M } \\
\left(\mathrm{g} \mathrm{kg}^{-1}\right)\end{array}$ & Sand & $\begin{array}{c}\text { Silt } \\
\left(\mathrm{g} \mathrm{kg}^{-1}\right)\end{array}$ & Clay & Texture & $\begin{array}{c}\text { CEC } \\
{\text { Cmolc } \text { kg }^{-1}}^{2}\end{array}$ & $\begin{array}{c}\text { DTPA-Mn } \\
\left(\mathrm{mg} \mathrm{kg}^{-1}\right)\end{array}$ \\
\hline Sharazor & 7.49 & 0.6 & 180 & 25 & 37.2 & 475.1 & 487.7 & SC & 41.15 & 2.40 \\
\hline Qaradagh & 7.65 & 0.7 & 25 & 17 & 383.5 & 370.3 & 246.2 & $\mathbf{L}$ & 26.93 & 3.46 \\
\hline $\begin{array}{l}\text { Bazian } \\
\text { Mawat }\end{array}$ & $\begin{array}{l}7.78 \\
7.48\end{array}$ & $\begin{array}{l}\text { 0.6 } \\
0.9\end{array}$ & $\begin{array}{c}100 \\
25\end{array}$ & $\begin{array}{l}15 \\
16\end{array}$ & $\begin{array}{c}55.8 \\
161.9\end{array}$ & $\begin{array}{l}430.5 \\
434.2\end{array}$ & $\begin{array}{l}513.7 \\
403.9\end{array}$ & $\begin{array}{l}\text { SC } \\
\text { SC }\end{array}$ & $\begin{array}{l}41.57 \\
39.42\end{array}$ & $\begin{array}{l}7.67 \\
5.42\end{array}$ \\
\hline Surdash & 7.9 & 0.4 & 430 & 9 & 91.6 & 490.4 & 418.0 & SC & 36.39 & 2.91 \\
\hline
\end{tabular}

SC, Silty Clay; L, Loam 


\section{Manganese adsorption in the studied soil}

The simplest way of characterizing adsorption is in terms of size of the adsorbing surface (or the maximum adsorption) and the affinity of the surface for the adsorbate (binding energy of sorption). For the adsorption equation to be helpful in the interpretation of the experimental results it should not only give a

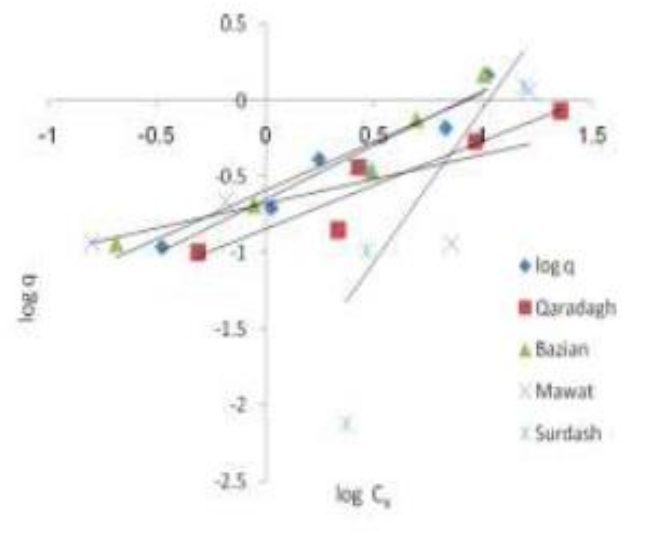

(a) satisfactory fit to the adsorption isotherm data, but also it should yield equation parameters with values meaningful in physicochemical sense (18). The results in Figure 1 ( $a$ and $b$ ) shows the Freundlich constants for $\mathrm{Mn}$ adsorptions were calculated from the fitting straight line between $\log \mathrm{q}$ and $\log \mathrm{Ce}$ at both temperature $(298 \& 318){ }^{\circ} \mathrm{K}$ in studied soils.

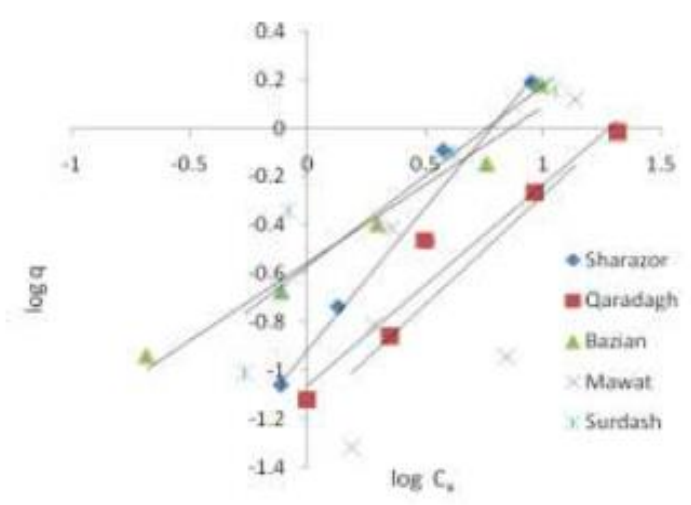

(b)

Figure 1. Linear form of Mn sorption in studied soil samples according to the Freundlich equation at $298{ }^{\circ} \mathrm{K}$ (a) and $318{ }^{\circ} \mathrm{K}(\mathrm{b})$.

Table 2 shows that higher value of $\left(\mathrm{K}_{\mathrm{f}}\right)$ in Freundlich equation ranged between 3.900117.22 at $298^{\circ} \mathrm{K}$, the highest value was in Surdash location, whereas lower value of $\left(\mathrm{K}_{\mathrm{f}}\right)$ shown in Bazian location. These results also indicated that the Surdash location had a high capability to $\mathrm{Mn}$ adsorption when compared with other locations. This may be due to the high values of soil reaction in Surdash soil; high value of $\mathrm{pH}$ in soil solution cause to increase adsorption process of Mn. Mattias, et al. (26). The highest value of $\mathrm{pH}$ means low amount of $\mathrm{H}^{+}$in soil solution and the competition process will be decrease between
$\mathrm{H}^{+}$and cations on the binding site, and then cause to adsorption of cations in the solution. (1). Further, the increase of adsorption process in Surdash might refer to the high amount of total $\mathrm{CaCO}_{3}$ in the soil, high amount of $\mathrm{CaCO}_{3}$ cause to increase adsorption process due to the hold of cations on the surface $\mathrm{CaCO}_{3}$ site (physical adsorption). Moharami \& Jalali (27) mentioned that the high value of Carbonate cause to increase $\mathrm{Mn}$ adsorption in the soil. Al-Janabi (4) and Al-Hassoon (3) observed that calcium carbonate cause to increase $\mathrm{Cu}$ adsorption process.

Table 2. Parameters of Mn adsorption for Freundlich, Temkin, Langmuir and Dubinin-

Radushkevich equations in studied area at temperature $298^{\circ} \mathrm{K}$

\begin{tabular}{|cccccccccc|}
\hline \multirow{2}{*}{ Locations } & \multicolumn{2}{c}{ Freundlich } & \multicolumn{2}{c}{ Temkin } & \multicolumn{2}{c|}{ Langmuir } & \multicolumn{2}{c|}{ Dubinin-Radushkevich } \\
\cline { 2 - 10 } & $\mathrm{K}_{\mathbf{f}}$ & $\mathbf{n}$ & $\mathrm{B}$ & $\mathrm{A}_{\mathbf{T}}$ & $\mathbf{q}_{\text {max }}$ & $\mathrm{K}_{\mathbf{L}}$ & qD & B $_{\text {D }}$ & E \\
\hline Sharazor & $\mathbf{4 . 4 6 4}$ & $\mathbf{1 . 4 0 7}$ & $\mathbf{0 . 3 4 3}$ & $\mathbf{2 . 4 5 1}$ & $\mathbf{0 . 9 0 4}$ & $\mathbf{0 . 3 9 0}$ & $\mathbf{1 . 0 2 7}$ & $\mathbf{0 . 3 6 4}$ & $\mathbf{1 . 1 7 3}$ \\
Qaradagh & $\mathbf{6 . 9 9 0}$ & $\mathbf{1 . 7 3 0}$ & $\mathbf{0 . 1 9 8}$ & $\mathbf{2 . 1 0 1}$ & $\mathbf{0 . 4 8 1}$ & $\mathbf{0 . 5 1 2}$ & $\mathbf{1 . 6 4 3}$ & $\mathbf{0 . 3 6 5}$ & $\mathbf{1 . 1 7 0}$ \\
Bazian & $\mathbf{3 . 9 0 0}$ & $\mathbf{1 . 5 7 4}$ & $\mathbf{0 . 3 0 6}$ & $\mathbf{3 . 4 5 3}$ & $\mathbf{0 . 5 9 2}$ & $\mathbf{1 . 1 2 0}$ & $\mathbf{1 . 1 6 5}$ & $\mathbf{0 . 2 5 7}$ & $\mathbf{1 . 3 9 6}$ \\
Mawat & $\mathbf{4 . 7 4 7}$ & $\mathbf{3 . 1 0 6}$ & $\mathbf{0 . 1 5 8}$ & $\mathbf{6 . 2 5 1}$ & $\mathbf{0 . 2 5 9}$ & $\mathbf{5 . 3 3 9}$ & $\mathbf{2 . 4 2 0}$ & $\mathbf{0 . 1 3 2}$ & $\mathbf{1 . 9 4 3}$ \\
Surdash & $\mathbf{1 1 7 . 2 2}$ & $\mathbf{0 . 4 9 6}$ & $\mathbf{0 . 6 2 6}$ & $\mathbf{2 . 1 6 7}$ & $\mathbf{0 . 0 2 8}$ & $\mathbf{0 . 1 4 5}$ & $\mathbf{4 . 7 0 2}$ & $\mathbf{2 . 8 5 7}$ & $\mathbf{0 . 4 1 8}$ \\
\hline
\end{tabular}

In Freundlich equation, (n) values interpret the strength of held cations by the soil, and the stability of formation complexes between cations and soil constituent. (9). The results in Table 2 shows that the Freundlich affinity values (n) for $\mathrm{Mn}$ in studied soils were ranged between (0.496-3.106), the highest value was in Mawat soil and the lowest value shown in Surdash soil. The value of (n) is less than one in Surdash soil. Temkin isotherm was drawn 
by plotting q against $\ln \mathrm{Ce}$ at both temperature (298 \& 318) ${ }^{\circ} \mathrm{K}$ in studied soils, as shown in Figure 2 (a \& b). Also the Temkin constants for Mn adsorption were calculated in Table 2. The values of the heat of adsorption (constant B) ranged between $(0.158-0.626)$, the highest

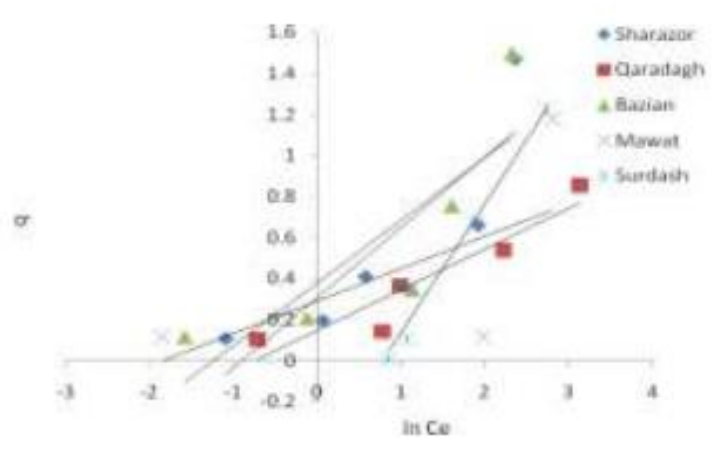

(a) value shows in Surdash location, while the lowest value shows in Mawat location. But the values of the maximum binding energy (At) ranged between (2.101 to 6.251), the highest value shows in Mawat, while the lowest value shows in Qaradagh locations.

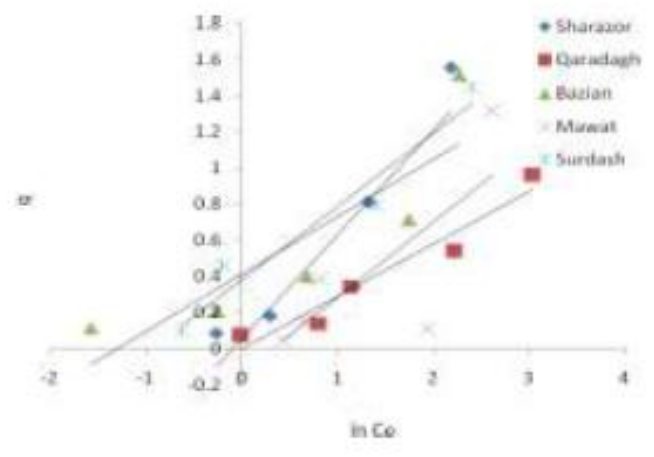

(b)

Figure 2. Linear form of Mn sorption in studied soil samples according to the Temkin equation at $298{ }^{\circ} \mathrm{K}$ (a) and $318^{\circ} \mathrm{K}(\mathrm{b})$.

The results of Langmuir constants for $\mathrm{Mn}$ adsorption shows in Table 2, these constants were calculated from the fitting straight line between $1 / \mathrm{q}$ and $1 / \mathrm{C}_{\mathrm{e}}$ at both temperature (298 $\& 318)^{\circ} \mathrm{K}$ in studied soils, as shown in Figure

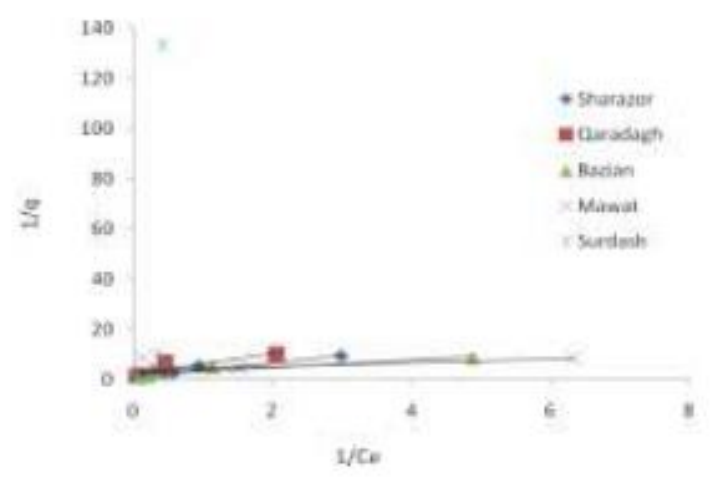

(a)
3 (a \& b). One of the benefits of the Langmuir equation is the ability of calculating the adsorption maximum and the binding energy from the regression line of equation.

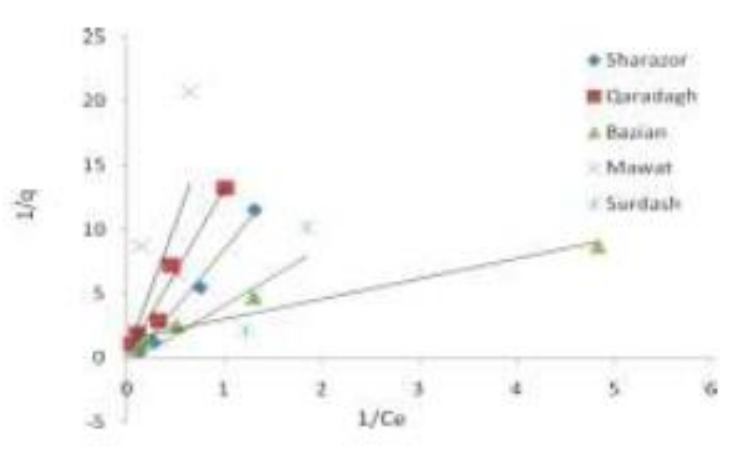

(b)

Figure 3. Linear form of Mn sorption in studied soil samples according to the Langmuir equation at $298{ }^{\circ} \mathrm{K}$ (a) and $318^{\circ} \mathrm{K}$ (b).

As shown in Table 2 the constant value of Langmuir equation, maximum adsorption $\left(\mathrm{q}_{\max }\right)$ which is measuring of soil adsorption capacity, ranged between (0.028-0.904) at temperature $298^{\circ} \mathrm{K}$ in all studied soil locations, the highest value was in Sharazor soil and the lowest value was shown in Surdash soil. The value of $\left(\mathrm{q}_{\max }\right)$ ranged between $(0.709-4.016)$ at temperature $318^{\circ} \mathrm{K}$ in all studied soil locations, the highest value was in Qaradagh soil and the lowest value was shown in Bazian soil. The Dubinin-Radushkevich constants for $\mathrm{Mn}$ adsorptions were calculated from the plotting straight line between $\ln$ qe and $\ln \left(1+1 / \mathrm{C}_{\mathrm{e}}\right)$ at both temperature $(298 \& 318){ }^{\circ} \mathrm{K}$ in studied soils, Figure 4 (a, b). 


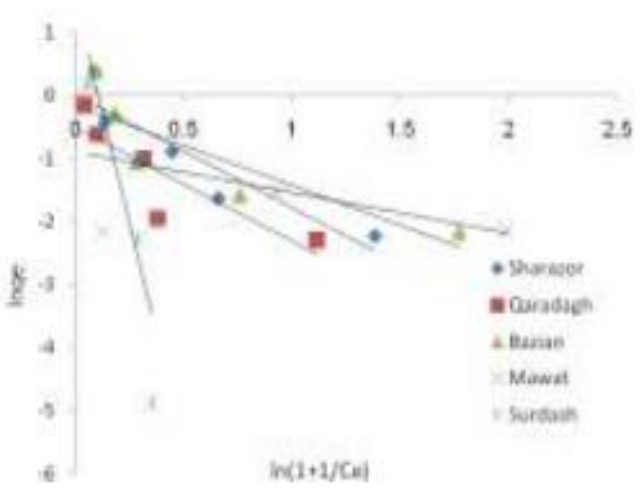

(a)

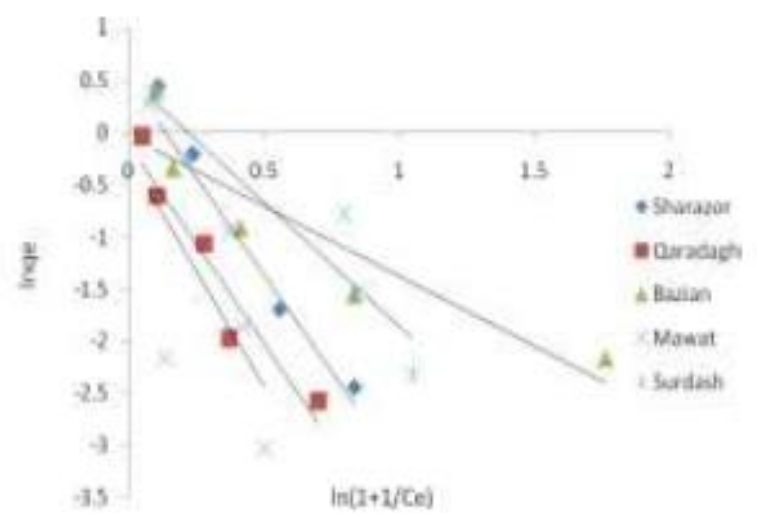

(b)

Figure 4. Linear form of Mn sorption in studied soil samples according to the Dubinin-

\section{Radushkevich equation at $298^{\circ} \mathrm{K}$ (a) and $318^{\circ} \mathrm{K}$ (b).}

According to Dubinin-Radushkevich equation shown in Table $(2,3)$ the highest value of adsorption capacity $\left(\mathrm{q}_{\mathrm{D}}\right)$ in Surdash locations were (4.702 and 1.683) at temperatures $(298 \&$ $318)^{\circ} \mathrm{K}$, respectively; this is may be due to the high amount of $\mathrm{pH}$ and calcium carbonate in Surdash location compared to other locations. The value of free energy (E) in DubininRadushkevich equation helps us to determine the mechanism of Mn adsorption in the studied locations. The value of (E) ranged from 0.418 1.943 and $0.751-1.355$ KJ $\mathrm{mol}^{-1}$ at temperatures $(298 \& 318)^{\circ} \mathrm{K}$, respectively. All these values less than $16 \mathrm{KJ} \mathrm{mol}^{-1}$, this means the mechanism of $\mathrm{Mn}$ adsorption in these five locations happening by ion exchange process according to Unlu \& Ersoz (31).

Table 3. Parameters of Mn adsorption for Freundlich, Temkin, Langmuir and Dubinin-

Radushkevich equations in studied area at temperature $318^{\circ} \mathrm{K}$

\begin{tabular}{|c|c|c|c|c|c|c|c|c|c|}
\hline \multirow[t]{2}{*}{ Locations } & \multicolumn{2}{|c|}{ Freundlich } & \multicolumn{2}{|c|}{ Temkin } & \multicolumn{2}{|c|}{ Langmuir } & \multicolumn{3}{|c|}{ Dubinin-Radushkevich } \\
\hline & $\mathbf{K}_{\mathbf{f}}$ & $\mathrm{n}$ & B & $\mathbf{A}_{\mathbf{T}}$ & $\mathbf{q}_{\max }$ & $\mathbf{K}_{\mathbf{L}}$ & QD & $\mathbf{B}_{\mathbf{D}}$ & $\mathbf{E}$ \\
\hline Sharazor & 8.224 & 0.847 & 0.580 & 1.091 & 1.666 & 0.066 & 1.646 & 0.752 & 0.815 \\
\hline Qaradagh & 11.561 & 1.205 & 0.289 & 1.010 & 4.016 & 0.019 & 1.123 & 0.768 & 0.807 \\
\hline Bazian & 3.588 & 1.553 & 0.317 & 3.648 & 0.709 & 0.890 & 1.029 & 0.272 & 1.355 \\
\hline Mawat & 15.066 & 1.109 & 0.419 & 1.388 & 1.890 & 0.026 & 1.268 & 0.886 & 0.751 \\
\hline Surdash & 3.703 & 1.342 & 0.407 & 2.546 & 2.269 & 0.098 & 1.683 & 0.481 & 1.020 \\
\hline
\end{tabular}

A comparison between different isotherms using for Mn adsorption

These figures were plotted according to the linear form of Freundlich, Langmuir, Timken, and Dubinin-Radushkevich equations. The fitness of these models is compared with the determination of coefficient $\left(\mathrm{R}^{2}\right)$ value of their regression lines, the standard error of estimate (RMSE) and Akaike information criterion (AIC). The results in (Figure 4 and Table 4, 5) indicate that the Dubinin-Radushkevich equation does not coincide very well with adsorption data of $\mathrm{Mn}$ as indicated by the $\mathrm{R}^{2}$ with mean value of 0.674 and 0.793 at 298 and $318^{\circ} \mathrm{K}$ temperature respectively, in comparison to Freundlich, Temkin and
Langmuir equations (Table 4, 5). The results in (Figure 3 and Table 4, 5) shows that the Langmuir equation does not fit well with adsorption data of $\mathrm{Mn}$ as indicated by the $\mathrm{R}^{2}$ with mean value of 0.669 and 0.807 at 298 and $318^{\circ} \mathrm{K}$ temperature respectively, in comparison to Freundlich and Temkin equations (Table 4,5 ). The Temkin equation gave a better fit of the equilibrium $\mathrm{Mn}$ adsorption data than the Langmuir and Dubinin-Radushkevich equations. (Figure 2 and Table 4, 5). The mean $\mathrm{R}^{2}$ value for the Temkin equation was higher than the Langmuir and Dubinin-Radushkevich equations these values were 0.749 and 0.807 at 298 and $318^{\circ} \mathrm{K}$ temperatures respectively. 
Generally, the Freundlich equation have good coincide with adsorption data of $\mathrm{Mn}$ in comparison to Temkin, Langmuir and Dubinin-Radushkevich equations equations, depending on the $\mathrm{R}^{2}$ and RMSE. The results in Table 4, 5 indicated that the mean values of the $\mathrm{R}^{2}, \mathrm{RMSE}$ and AIC were $0.751,0.283$ and -13.515 respectively at $298^{\circ} \mathrm{K}$ temperature and means $0.829,0.205$ and -16.318 respectively at $318^{\circ} \mathrm{K}$ temperature Fig. $1 \&$ 2. Jar Allah (21) indicated that Freundlich equation have the best fit to Iron adsorption. The above equation describes Mn adsorption well over the range of equilibrium $\mathrm{Mn}$ concentrations used in this study. The effectiveness of these equations in accordance to these results can be arranged as

follows:Freundlich > Temkin> Langmuir > Dubinin-Radushkevich. These results are in agreement with earlier reportes by Willett and Bond (34) which indicated that both Langmuir and Freundlich equations gives best fit to the Mn adsorption data.

\section{Effect of temperature on Mn adsorption:}

Generally, the Freundlich constant $\left(\mathrm{K}_{\mathrm{f}}\right)$ values of $\mathrm{Mn}$ adsorption increased with increasing temperature from 298 to $318^{\circ} \mathrm{K}$ in Sharazor, Qaradagh and Mawat locations as shown in Table 4 and 5. The higher value of constant $\left(\mathrm{K}_{\mathrm{f}}\right)$ found in Surdash soil at $298^{\circ} \mathrm{K}$ temperatures. This was also clear in the higher $\mathrm{Mn}$ adsorption capacity of this soil in comparison with other soils.

Table 4. Determination of coefficient $\left(R^{2}\right)$, standard error of estimate (RMSE) and Akaike information criterion (AIC) at 298 K for linear Freundlich, Temkin, Langmuir and DubininRadushkevich equations

\begin{tabular}{|c|c|c|c|c|c|c|c|c|c|c|c|c|}
\hline \multirow[t]{2}{*}{ Locations } & \multicolumn{3}{|c|}{ Freundlich } & \multicolumn{3}{|c|}{ Temkin } & \multicolumn{3}{|c|}{ Langmuir } & \multicolumn{3}{|c|}{ Dubinin-Radushkevich } \\
\hline & $\mathbf{R}^{2}$ & RMSE & AIC & $\overline{\mathbf{R}^{2}}$ & RMS & AIC & $\overline{\mathbf{R}^{2}}$ & RMSE & AIC & $\mathbf{R}^{2}$ & RMSE & $\overline{\text { AIC }}$ \\
\hline Sharazor & 0.953 & 0.110 & -20.599 & 0.771 & 0.302 & -10.511 & 0.950 & 0.899 & 28.804 & 0.857 & 0.445 & -6.655 \\
\hline Qaradagh & 0.893 & 0.148 & -17.664 & 0.883 & 0.123 & -19.539 & 0.787 & 2.015 & 8.451 & 0.745 & 0.524 & -5.014 \\
\hline Bazian & 0.922 & 0.143 & -18.004 & 0.695 & 0.360 & -8.767 & 0.891 & 1.232 & 3.530 & 0.749 & 0.590 & -3.833 \\
\hline Mawat & 0.384 & 0.380 & -8.219 & 0.433 & 0.388 & -8.010 & 0.303 & 3.372 & 13.600 & 0.299 & 0.934 & 0.767 \\
\hline Surdash & 0.605 & 0.635 & -3.088 & 0.967 & 0.104 & -21.213 & 0.412 & 51.433 & 40.849 & 0.721 & 1.231 & 3.525 \\
\hline Means & 0.751 & 0.283 & -13.515 & 0.749 & 0.255 & -13.608 & 0.669 & 11.790 & 19.047 & 0.674 & 0.745 & -2.242 \\
\hline
\end{tabular}

Table 5. Determination of coefficient $\left(\mathbf{R}^{2}\right)$, standard error of estimate (RMSE) and Akaike information criterion (AIC) at $318 \circ \mathrm{K}$ for linear Freundlich, Temkin, Langmuir and DubininRadushkevich equations

\begin{tabular}{|c|c|c|c|c|c|c|c|c|c|c|c|c|}
\hline \multirow[t]{2}{*}{ Locations } & \multicolumn{3}{|c|}{ Freundlich } & \multicolumn{3}{|c|}{ Temkin } & \multicolumn{3}{|c|}{ Langmuir } & \multicolumn{3}{|c|}{ Dubinin-Radushkevich } \\
\hline & $\mathbf{R}^{2}$ & RMSE & AIC & $\mathbf{R}^{2}$ & RMS & AIC & $\mathbf{R}^{2}$ & RMSE & AIC & $\mathbf{R}^{2}$ & RMSE & $\overline{A I C}$ \\
\hline Sharazor & 0.954 & 0.123 & -19.480 & 0.833 & 0.285 & -11.109 & 0.981 & 0.705 & -2.052 & 0.903 & 0.413 & -7.409 \\
\hline Bazian & 0.971 & 0.086 & -23.036 & 0.753 & 0.324 & -9.813 & 0.936 & 0.951 & 0.939 & 0.836 & 0.473 & -6.041 \\
\hline Mawat & 0.456 & 0.467 & -6.176 & 0.568 & 0.398 & -7.759 & 0.400 & 7.025 & 20.941 & 0.424 & 1.105 & 2.448 \\
\hline Means & 0.829 & 0.205 & -16.318 & 0.807 & 0.251 & -13.543 & 0.807 & 2.404 & 6.345 & 0.793 & 0.550 & -5.539 \\
\hline
\end{tabular}

The effect of temperature on Mn adsorption can be expressed through some thermodynamic parameters of $\mathrm{Mn}$ adsorption like $\left(\Delta \mathrm{H}^{\circ}\right),\left(\Delta \mathrm{G}^{\circ}\right)$ and $\left(\Delta \mathrm{S}^{\circ}\right)$ in these studied soils. The value of enthalpy $\left(\Delta \mathrm{H}^{\circ}\right)$ in these soils we can express the heat energy transferred into or out of a system during Mn adsorption process in these soils. Generally, the value of $\left(\Delta \mathrm{H}^{\circ}\right)$ of $\mathrm{Mn}$ adsorption in the Sharazor, Qaradagh and Mawat soils were negative as shown in Table (6) which indicated that the $\mathrm{Mn}$ adsorption processes in these soils were exothermic reactions (heat transfer in from the system to the surroundings). While, positive value recorded in Bazian and Surdash soils which indicated that the $\mathrm{Mn}$ adsorption processes in both locations were endothermic reactions (heat transfer from surroundings in to the system). As shown in the Table 6 the value of $\left(\Delta \mathrm{H}^{\circ}\right)$ for Sharazor, Qaradagh, Bazian, Mawat and Surdash were $-23.869,-31.793,4.442,-86.968$ 
and 21.028 respectively. The lowest values for $\left(\Delta \mathrm{H}^{\circ}\right)$ were found in the Mawat soil. This would be expected due to the present of lower amount of $\mathrm{T}^{-\mathrm{CaCO}_{3}}$ and $\mathrm{pH}$ value in Mawat soil in comparison with the other soils, while the Surdash soil has higher value of $\left(\Delta \mathrm{H}^{\circ}\right)$ due to the high amount of T.CaCO 3 in the Surdash soil with the higher value of soil $\mathrm{pH}$. A lower value of $\Delta \mathrm{H}^{\circ}$ of Mn adsorption in Mawat may be attributed to more specific adsorption of Mn in this soil. Battacharyya and Tenuv (7), and Al-Hassoon, et al.( 2 ) reported that the adsorption of cations in soils affected by soil properties as $\mathrm{pH}$, calcium carbonate content, organic matter, ...The values of $\left(\Delta S^{\circ}\right)$ in studied soils were negative in the Sharazor, Qaradagh and Mawat soils. Whereas, positive in Bazian and Surdash soils. $\Delta \mathrm{S}^{\circ}$ used to measure of the order or disorder formed in a system during a given reaction. Apparently one would look for that the adsorption of ions from solution would form more order in a given system since the random movement of ionic species in solution has become subjected to prevent adsorption force of the surface. The $\left(\Delta \mathrm{S}^{\circ}\right)$ values of these soils were in the order of
Surdash > Bazian> Sharazor > Qaradagh > Mawat. The higher $\left(\Delta S^{\circ}\right)$ value present in Surdash soil is could be due to the high amount of $\mathrm{T}^{-} \mathrm{CaCO}_{3}$ may be of the high activity of $\mathrm{Ca}^{+2}$ which is react rapidly with $\mathrm{Mn}$ in that system. These results indicated that Surdash soils adsorbed higher amounts of Mn as compared with the other soils. The values of free energy found $\left(\Delta \mathrm{G}^{\circ}\right)$ were negative at both temperatures and in all five locations except Sharazor, Qaradagh and Mawat locations which is positive at temperature $318^{\circ} \mathrm{K}$ as shown in Table (6), obviously there was a increase in $\left(\Delta \mathrm{G}^{\circ}\right)$ with increasing in temperature from 298 to $318^{\circ} \mathrm{K}$ in Sharazor, Qaradagh and Mawat locations. While, the value of $\left(\Delta \mathrm{G}^{\circ}\right)$ increase more negative value with increase temperature from 298 to $318^{\circ} \mathrm{K}$ in Bazian and Surdash locations. The results indicated that the reaction in all studied soil locations at temperature $298{ }^{\circ} \mathrm{K}$ is spontaneous, also the reaction stay spontaneous with increase temperature to 318 ${ }^{\circ} \mathrm{K}$ in both Bazian and Surdash locations. The negative value of $\left(\Delta \mathrm{G}^{\circ}\right)$ indicated that the reaction is spontaneous (13).

Table 6. Calculated values of enthalpy $\left(\Delta \mathrm{H}^{\circ}\right)$, free energy $\left(\Delta \mathrm{G}^{\circ}\right)$ entropy $\left(\Delta S^{\circ}\right)$ and $(\mathrm{K})$ for the $M n$ adsorption in studied area:

\begin{tabular}{|c|c|c|c|c|c|}
\hline Locations & Temperatures $\left({ }^{\circ} \mathbf{K}\right)$ & $\begin{array}{c}\Delta \mathrm{H}^{\circ} \\
\left(\mathrm{k} . \mathrm{mol}^{-1}\right)\end{array}$ & $\begin{array}{c}\Delta \mathrm{G}^{\circ} \\
\left(\mathrm{kJ} \mathrm{mol}^{-1}\right)\end{array}$ & $\begin{array}{c}\Delta \mathbf{S}^{\circ} \\
\left(. \mathrm{J} \mathrm{mol}^{-1} \mathbf{k}^{-1}\right)\end{array}$ & $\mathbf{K}^{\circ}$ \\
\hline \multirow{2}{*}{ Sharazor } & 298 & \multirow[t]{2}{*}{-23.869} & -1.114 & -76 & 1.568 \\
\hline & 318 & & 0.413 & -76 & 0.855 \\
\hline \multirow[t]{2}{*}{ Qaradagh } & 298 & \multirow[t]{2}{*}{-31.793} & -0.407 & -105 & 1.178 \\
\hline & 318 & & 1.700 & -105 & 0.526 \\
\hline \multirow[t]{2}{*}{ Bazian } & 298 & \multirow[t]{2}{*}{4.442} & -1.347 & 19 & 1.723 \\
\hline & 318 & & -1.736 & 19 & 1.928 \\
\hline \multirow{2}{*}{ Mawat } & 298 & \multirow{2}{*}{-86.968} & -2.061 & -285 & 2.297 \\
\hline & 318 & & 3.638 & -285 & 0.253 \\
\hline \multirow{2}{*}{ Surdash } & 298 & \multirow{2}{*}{21.028} & -0.198 & 71 & 1.083 \\
\hline & 318 & & -1.623 & 71 & 1.847 \\
\hline
\end{tabular}

The Mn adsorption data were better described by Freundlich isotherm than were described by Temkin, Langmuir and Dubinin-Radushkevich isotherms. The majot properties of soil affecting Mn adsorption in calcareous soil are Calcium carbonate content and $\mathrm{pH}$ of the soil. The adsorption of $\mathrm{Mn}$ increase with increases both $\mathrm{pH}$ and calcium carbonate content in the soil. Thermodynamic parameter shows that $\mathrm{Mn}$ adsorption in five studied soils was spontaneous at temperature $298^{\circ} \mathrm{K}$. The adsorption of Mn in Sharazor, Qaradagh and Mawat soils were exothermic reactions. While the $\mathrm{Mn}$ adsorption processes in both Bazian and Surdash locations were endothermic reactions. This suggests that the adsorption capacity of Bazian and Surdash increased with an increase temperature. Further more research requires determining effect of the type of the mineral on the Mn adsorption in the studied locations.

\section{REFRENCES}

1. Abat, M.; Michael J. McLaughlin, Jason K. Kirby, Samuel and P. Stacey. 2012. Adsorption and desorption of copper and zinc in tropical peat soils of Sarawak, Malaysia. Geoderma 175-176: $58-63$

2. Al-Hassoon, S. N. H., Al-Hayani, A.S.J.Z., and Al-Obaidi, M. A. J. 2019. Adsorption isotherm of 
lead on calcium carbonate. Iraqi Journal of Agricultural ciences. 50(special issue):48-53

3. Al-Hassoon, S.N.H., Al-Hayani, A.S >J.Z., and Al-Obaidi, M. A.J. 2019. Copper adsorption in two different soil texture. 50(2):638-645

4. Al-Janabi, F. K. and Al-Robiaee, M. A. 2016. Kinetic of copper adsorption in calcareous soil. The Iraqi Journal of Agricultural Sciences. 47(2): 621-626

5. Barber, S.A. 1995. Soil Nutrient Bioavailability. A Mechanistic Approach, 2nd ed. John Wiley and Sons, New York, USA

6. Barrow, N.J.; and V.C. J. Cox. 1992. The effects of $\mathrm{pH}$ and chloride concentration on mercury sorption. II. By a soil. Soil Sci. 43(2): 305-312

7. Battacharyya, S. and A. Tenuv. 2017. Soil Properties Affecting Adsorption. World News of Natural Sciences 9: 19-34

8. Bradl, H. B. 2004. Adsorption of heavy metal ions on soils and soils constituents. Journal of Colloid and Interface Science 277: 1-18

9. Buchter, B., B. Davidoff, M.C. Amacher, C. Hinz, I.K. Iskandar, and H.M. Selim. 1989. Correlation of Freundlich $\mathrm{Kd}$ and $\mathrm{n}$ retention parameters with soils and elements. Soil Science 148: 370-379

10. Cavallaro, N.; and M.B. McBride. 1980. Activities of $\mathrm{CU}^{2+}$ and $\mathrm{Cd}^{2+}$ in soil solutions as affected by pH. Soil Sci. Soc. Am. J. 44: 729-732

11. Dabrowski, A., 2001. Adsorption-from theory to practice, Adv. Colloid Interface Sci.93. P: 135224

12. Das, B.; Mondal, N.K.; Bhaumik, R.; and P. Roy. 2014. Insight into adsorption equilibrium, kinetics and thermodynamics of lead onto alluvial soil. Int. J. Environ. Sci. Technol. 11:1101-1114

13. Dawodu, F.A.; and K. G. Akpomie. 2014. Simultaneous adsorption of $\mathrm{Ni}(\mathrm{II})$ and $\mathrm{Mn}$ (II) ions from aqueous solution unto a Nigerian kaolinite clay. Journal of material research and Technology. 3(2):129-141

14. Dubinin, M. M. and L. V. Radushkevich. 1947. Equation of the characteristic curve of activated charcoal.Chem. Zentr., 1: 875-890

15. Dubinin, M. M., 1960. The potential theory of adsorption of gases and vapors for adsorbents with energetically non-uniform surface. Chem. Rev., 60, $235-266$

16. Ducic, T., and A. Polle. 2005. Transport and detoxification of manganese and copper in plants. Brazilian Plant Physiology 17 (1): 103-112

17. Freundlich, H. M. F. 1906. Over the adsorption in solution. J Phys Chem. 57:385-471

18 Holford, I.C.R. 1982. The comparative significance and utility of Freundlich and Langmuir parameters for characterizing sorption of phosphate in soils. Aust. J. Soil Res. 20:233-242
19. International Center for Agricultural Research in Dry Areas (ICARDA). 2013. Methods of soil, plant, and water analysis: A manual for the West Asia and North Africa region. $3^{\text {rd }}$ ed. ICARDA, Beirut, Lebanon

20. Iskander, A.L.; Khald, E.M. ; and A.S. Sheta. 2011. Zinc and manganese sorption behavior by natural zeolite and bentonite. Annals of Agricultural Science. 56, 43-48

21. Jar Allah, A. Kh., Al-Uqaili, J. K., and Rahi, H.A.S. 2016. Effect of some soil properties on iron sorption. The Iraqi Journal of Agricultural Sciences. 47(4): 1056-1063

22. Kent, D.B.; Abrams, R.H.; Davis, J.A. ; Coston, J.A. ; and D.R. Le Blanc, 2000. Modeling the transport of zinc under variable chemical conditions in a contaminated aquifer. Water Resour. Res. 36 (12) 3401

23. Langmuir, I. 1918. The adsorption of gases on plane surfaces of glass, mica and platinum. J Am Chem. Soc. 40:1361-1368

24. Lindsay, W.L., and W.A. Norvell. 1978. Development of DTPA micronutrient soil test for zinc, iron, manganese and copper. Soil Sci. Soc. Amer. Proc. 42:421-428

25. Martinez, C.E.; and H.L. Motto. 2000. Solubility of lead, zinc and copper added to mineral soils. Environ. Pollut. 107(1): 153-8

26. Mattias, J. L.; C. A. Ceretta; C. N. Nesi; E. Girotto; E.E. Trentin; C. R. Lourenzi, and R.C.B. Vieira. 2010. Copper, Zinc and Manganese in soils of two watersheds in Santa Catarina with intensive use of pig slurry (1). R. Bras. Ci. Solo, 34:14451454

27. Moharami , S. and M. Jalali. 2013. Effects of cations and anions on iron and manganese sorption and desorption capacity in calcareous soils from Iran. Environ Earth Sci., 68:847-858

28. Morel, F. M. M. and J. G. Hering. 1993. Principles and Applications of Aquatic Chemistry. John Wiley and Sons: New York, $588 \mathrm{p}$

29. Temminghoff, E. J. M.; Van Der Zee, S. E. A. T. M. and Keizer, M. G. 1994. The influence of $\mathrm{pH}$ on the desorption and speciation of copper in a sandy soil. J. Soil Sci., 158, 398-407

30. Temminghoff, E.J.M.; Van der Zee, S.E.A.T.M. and F.A.M. de Haan. 1995. Speciation and calcium competition effects on cadmium sorption by sandy soil at various pHs. Eur. J. Soil Sci. 46(4): 649-655

31. Unlu N, and M. Ersoz. 2006. Adsorption characteristics of heavy metal ions onto a low cost biopolymeric sorbent from aqueous solutions. Journal of Hazardous Materials; 136: 272-280.

32. van Langen, B. 1993. Manual for chemical soil analysis. Dept. Soil Sci. Geol., Agric. Univ. Wageningen, Wageningen, Netherlands 
33. Van Reeuwijk, L.P. 1992. Procedures for soil analysis. No. 9. International Soil Reference and Information Centre/Food and Agriculture Organization of the United Nations, Wageningen,Netherlands
34. Willett, I.R., and W.J. Bond. 1995. Sorption of manganese, uranium and radium by highly weathered soils. Journal of Environment Quality $24,834-845$. 